\title{
Exploring the Effect of Product Type Differences on R\&D Outsourcing and Knowledge Sharing in High-Tech Industry
}

\author{
Bruce C. Y. Lee ${ }^{1}$, Tun-Chih Kou ${ }^{1} \&$ Chiou-Fong Wei ${ }^{1}$ \\ ${ }^{1}$ Graduate Institute of Business Administration, Fu Jen Catholic University, Taiwan \\ Correspondence: Tun-Chih Kou, Graduate Institute of Business Administration, Fu Jen Catholic University, New \\ Taipei City, Taiwan. Tel: 886-952-557-696. E-mail: fredonef@hotmail.com
}

Received: October 16, 2013

Accepted: December 12, 2013 Online Published: January 20, 2014

doi:10.5539/ijbm.v9n2p80

URL: http://dx.doi.org/10.5539/ijbm.v9n2p80

\begin{abstract}
During the past decade, brand owners have preferred to use research and development (R\&D) outsourcing to integrate activities based on value chain considerations. Today, however, this preference has changed because of competitive pressure in the high-tech industry, and brand owners are opting to secure R\&D resources internally. This study focuses on how to properly allocate R\&D resources and leverage the knowledge capabilities of contract manufacturer to maximize the benefits of each product type. This study was conducted from the point of view of a brand owner, and a case study was also used. The effects of R\&D outsourcing levels on knowledge sharing between brand owners and contract manufacturers were investigated by analyzing four product types: auxiliary products, core products, innovative products, and exploratory products. In this study, knowledge sharing was divided into technology and market knowledge sharing. Two conclusions were drawn based on the results. First, the results indicated that managers adopt distinct levels of R\&D outsourcing according to the product type. Second, product types with matched R\&D outsourcing levels caused dissimilar results regarding technology and market knowledge sharing between brand owners and contract manufacturers. Managerial implications and suggestions are also provided in this paper.
\end{abstract}

Keywords: research and development (R\&D) outsourcing, knowledge sharing, product type

\section{Introduction}

Research and development (R\&D) outsourcing is a crucial topic in the high-tech industry. Firms must make a critical decision between outsourcing $R \& D$ and maintaining in-house R\&D. Two divergent opinions regarding $R \& D$ outsourcing exist. Various studies indicated that $R \& D$ outsourcing strategies positively affect the performance of firms. Firms also rely on external suppliers to acquire R\&D services to obtain or sustain a competitive advantage (Leiblein \& Miller, 2003; Quinn, 2000) and reduce costs (Chalos \& Sung, 1998). Gottfredson, Puryear, and Phillips (2005) suggested that firms must focus on core competencies and outsource other value-added activities to suppliers. Strategic outsourcing enables firms to reduce costs and effectively develop new products (Araujo, Dubois, \& Gadde, 1999). In the high-tech industry, brand owners focus only on sales and marketing, and outsource R\&D to contract manufacturers to profit further. For example, HP, Dell, Sony, and Acer outsource R\&D for product design to contract manufacturers such as Foxconn and Quanta Computer.

Another previous study emphasized the negative effects of R\&D outsourcing strategies, indicating that major outsourcing advantages continually diminish because of rapid changes in the market (Lonsdale, 1999). Furthermore, studies have indicated that outsourcing R\&D causes firms to lose key skills and knowledge (Gonzalez et al., 2005), and that internal R\&D resources increase the success of product innovation in the market (Roper et al., 2008). Confronted with competitive pressure in the high-tech industry, brand owners are increasingly resorting to in-house $\mathrm{R} \& \mathrm{D}$ in recent years. They seek to increase product differentiation and attract the attention of customers to obtain a competitive advantage in the market. Brand owners focus on one product line, and develop new product lines for diversification. They use in-house R\&D resources to design potential products, and use R\&D outsourcing for high-integration and mature products. Therefore, Determining whether or not to outsource $R \& D$ or how much $R \& D$ to outsource remains challenging.

Market and technology knowledge is crucial for organizational growth, value creation, and gaining a competitive advantage (Conner \& Prahalad, 1996). In addition, several benefits are associated with knowledge 
sharing (Kautz \& Mahnke, 2003). Knowledge sharing is becoming increasingly important because brand owners seek to leverage the knowledge capabilities of contract manufacturer. Various scholars argued that firms must internationalize R\&D functions to cut costs and gain knowledge (Hagedoorn, 1993). In-house R\&D was deemed essential to improve products, and it is also required for successfully combining the necessary knowledge to introduce new products (Zahra \& George, 2002). Therefore, distinct products exist because firms apply various associated knowledge resources (Ganotakis \& Love, 2012). An empirical analysis suggested that external R\&D resources complement internal $\mathrm{R} \& \mathrm{D}$ knowledge sources, and that knowledge of new product innovation is derived from both in-house and external R\&D sources (Ganotakis \& Love, 2012). Therefore, the main consideration of firms is to either use in-house $R \& D$ or to outsource $R \& D$ by using various knowledge-sharing strategies depending on the product type.

The purpose of this study is to investigate how to properly and flexibly allocate $R \& D$ resources and leverage the technology and market knowledge of contract manufacturers to maximize the benefits of each product type from the perspective of a high-tech industry brand owner. This study consists of three phases. First, the R\&D outsourcing level was determined and applied to the various product types produced by the brand owner. The effects of the R\&D outsourcing level on technology and market knowledge sharing were examined based on various product types. Second, a case study approach was selected as the method used in this study. In addition, 24 product managers who oversaw eight product lines were interviewed, and the data were gathered and analyzed. Third, a framework was developed to understand R\&D outsourcing strategies and knowledge sharing based on the product types produced by brand owner. The developed framework is an analytical tool that can be applied in future studies and used by managers to analyze R\&D outsourcing strategies and leverage knowledge sharing.

\section{Literature Review and Research Questions}

\subsection{R\&D Outsourcing}

A resource-based approach was used as a reference for determining whether or not a firm should use an R\&D outsourcing strategy. According to the resource-based view, firms execute $R \& D$ outsourcing to complement the resources and knowledge capabilities of the firm (Quinn \& Hilmer, 1994). Firms use R\&D outsourcing to integrate activities based on the value chain into product development. In addition, firms rely on suppliers for R\&D outsourcing services to attain a competitive advantage (Nixon \& Woo, 2003) and reduce costs (Chalos \& Sung, 1998). Firms also execute product development according to technical collaborative agreements, especially in research-intensive industries (Belderbos, Carree, \& Lokshin, 2004). Conversely, Caputo and Palumbo (2005) indicated that outsourcing results in a loss of market share and customers, causing quality problems. In addition, using internal $\mathrm{R} \& \mathrm{D}$ resources increases the success of innovative products in the market (Roper et al., 2008).

The most effective method to determining whether or not to outsource $R \& D$ is to decide on the level of $R \& D$ outsourcing required according to the situation. A previous study asserted that firms must focus on competitive advantage and use outsourcing strategies to maximally benefit from technology solutions (Cesaroni, 2004). Another previous study suggested that internal $R \& D$ and the knowledge gained from external parties affect the innovative ability and success of firms (Artz, Norman, Hatfield, \& Cardinal, 2010).

\subsection{Knowledge Sharing}

Market and technology knowledge is crucial for organizational growth, knowledge value creation, and attaining a competitive advantage (Conner \& Prahalad, 1996). Therefore, organizations seek to leverage their knowledge-related competencies to sustain a competitive advantage (Kankanhalli, Tan, \& Wei, 2005). New knowledge is acquired through cooperation and the subsequent knowledge exchange between organizations (Santoro, Bierly, \& Gopalakrishnan, 2007). In recent years, numerous benefits are associated with knowledge sharing (Kautz \& Mahnke, 2003). Nilakanta, Miller, and Zhu (2006) suggested that organizational knowledge affects the overall performance of the firm, and also affects the competitiveness of an organization. Knowledge sharing is a vital step that firms must take to attain a competitive advantage (Kogut \& Zander, 1992). The knowledge and capabilities of contract manufacturers influence the competitiveness of brand owners (Asmus \& Griffin, 1993), which influences the process of providing information, knowledge, and feedback on products and technology (Hansen, 1999). A previous study noted that knowledge exchange improves the innovative abilities of firms (Spithoven, Frantzen, \& Clarysse, 2010). There is also strong evidence that there is a positive connection between knowledge activities and innovation output (Laursen \& Salter, 2006). This suggests a link to external knowledge sources that improve the economic scope of firms because firms leverage external resources effectively (Love \& Roper, 2009). 
Various knowledge sources influence the performance of firms (Artz et al., 2010). Existing literature indicates two sources for new product development success. One source is technology competence; the other is market competence. Technology knowledge is defined as the knowledge of product design and engineering. Market knowledge is defined as the knowledge of customer preferences for market trends (Danneels, 2002). In this study, knowledge sharing was divided into technology and market knowledge sharing.

\subsection{The Effects of R\&D Outsourcing and Knowledge Sharing}

Evidence from a previous study indicates that the motivation of firms to outsource R\&D overseas involves identifying local advantages regarding low costs and technology information (Ghemawat, 2003). External knowledge sources provide firms with absorptive capacity benefits (Cohen \& Levinthal, 1990; Le Bas \& Sierra, 2002). Scholars argued that firms decide to internationalize R\&D to reduce costs and gain new knowledge (Hagedoorn, 1993). However, Oxley (1997) indicated that knowledge transfers related to R\&D outsourcing cause hazards. These hazards involve conflicts that influence the decision on whether or not to outsource (Henisz \& Williamson, 1999).

In-house R\&D improves products, and enables necessary knowledge to be combined to successfully introduce new products (Zahra \& George, 2002). In-house R\&D activities sustain external knowledge sources (Pittaway, Robertson, Munir, Denyer, \& Neely, 2004).

Technology sharing allows firms to use R\&D resources efficiently (Tatikonda \& Stock, 2003). Karlsson and Sköld (2007) stated that firms must decide which technologies to develop internally and which technologies must be outsourced to external parties. Therefore, firms must consider the challenge of developing technology internally (Venkatesan, 1992). An empirical analysis suggested that external R\&D resources complement internal R\&D knowledge sources, and that the knowledge of new product innovation is derived from in-house R\&D and external partners (Ganotakis \& Love, 2012). Therefore, the major concern involved in new product development (NPD) is determining whether to use internal R\&D or to rely on external R\&D sources by using several knowledge-sharing strategies.

\section{Methodology}

A case study methodology was selected to be used in this study because case studies were used to tease out commonalities, dissimilarities, and applications of a process, here the decision whether to outsource R\&D. Yin (1994) suggested that the case study research method be used for collecting a substantial amount of evidence and information. The case study method also entails an empirical inquiry used for investigating contemporary phenomena within a real-life context, in which the phenomena and context are not evident and multiple sources of evidence are used.

\subsection{Research Target}

We selected a brand owner in the high-tech industry as the informant for this case study. The high-tech industry is known for intense new product development, and brand owners play a critical role in deciding R\&D outsourcing strategies and determining approaches for using the knowledge capabilities of contract manufacturers through knowledge sharing; these strategies and approaches vary depending on product types. One brand owner was selected to participate in this study. The brand owner's organization comprised 55,000 employees from branches in Europe, America, Asia, and Australia. The product lines were extremely diverse, and included products such as notebooks, tablets, motherboards, VGA cards, liquid crystal display (LCD) monitors, servers, DVD-ROMs, smart phones, and other information technology (IT) products. The total revenue of these product lines reached US\$14 billion in 2012. The brand owner was innovative and flexible. Some products were kept in-house to maintain a competitive advantage, whereas R\&D outsourcing was used for other products to leverage the knowledge capabilities of contract manufacturers.

The product types were classified into two dimensions: new technology versus existing technology, and high-competition market versus low-competition market. To allocate R\&D resources efficiently, the brand owner used various R\&D outsourcing levels depending on the product type. Furthermore, the brand owner occasionally shared technology or market knowledge with contract manufacturers to obtain information. However, the brand owner chose not to be candid when sharing information to sustain a competitive advantage and confidentiality.

A two-phase approach was applied to analyze the various product lines of this brand owner. During the first stage, three researchers categorized the product lines into a product portfolio. The product lines were then classified and selected, and the director of each product line was approached. The researchers explained the purpose of the study and consulted the product directors to appropriately categorize each product line. During 
the second stage, three product line managers working on the same product line were approached, the purpose of this study was explained to them, and they were subsequently interviewed. In total, eight product lines were selected for the case study. Three product managers for each product line were interviewed, including 24 product managers who oversaw the eight product lines. This study focused on knowledge sharing between the brand owner and contract manufacturers. The interviews provided data on each of the four product types. The objective of the researchers was to determine the possibilities of R\&D outsourcing strategies and knowledge sharing for each product type. The four product types are presented as follows:

\section{Product Type 1: Low-competition market/existing technology (auxiliary product).}

The products in this category were based on existing technology and sold in a low-competition market. This type of product was in the declining stage of the market. Therefore, some competitors may have considered withdrawing from this market, and few new firms considered entering this market. The technology was mature and it was difficult for firms to develop new applications for the future use of these products. The brand owner decided to continue producing this product type, despite the apparent lack of potential benefits, because it was an accessory that could be bundled with major products and sold to customers. This allowed the brand owner to sell the product for additional revenue and increased market awareness. Therefore, this product was classified as an auxiliary product.

\section{Product Type 2: High-competition market/existing technology (core product).}

The products in this category comprised existing technology and sold in a high-competition market. These products were mature. The market trend was predicted to grow and the market total was substantial. Although the annual increases were low, the market attracted most existing firms that sought to obtain the market share of other competitors. The second product type was existing technology, but the brand owner attempted to make a difference by attracting the attention of end-consumers (e.g., industrial design). Brand owners usually focus considerable energy and effort on this product type because of the major revenue potential. This product was, therefore, classified as the core product.

\section{Product Type 3: Low-competition market/new technology (exploratory product).}

Products in the third category were based on new technology and sold in a low-competition market. The market trend was not clear for this product type. Because the technology was the newest and most unique available, the total investment was considered high. In addition, there was no guarantee of its future success. Most brand owners preferred not to develop these products during the early stage of new technology research. Therefore, the competitors monitored each other to make decisions regarding new technology. Therefore, this product was classified as an exploratory product.

\section{Product Type 4: High-competition market/new technology (innovative product).}

Products in the fourth category comprised new technology and sold in a high-competition market. A high percentage of firms sought to apply new technology to this product type because brand owners believed that the market trend possessed the potential to increase rapidly. Firms acknowledged that there is a high probability that a product type could be the market leader if brand owners predict the market trend correctly. Therefore, numerous brand owners were attracted to this new market. They allocated a substantial amount of resources to develop products of this type. This caused the market to become highly competitive; therefore, this product was classified as an innovative product.

Each product line was presented as a unit of analysis, and two lines involving each product type were analyzed. The data analysis revealed detailed information on these eight product lines. The empirical sampling frame is illustrated in Figure 1. The patterns demonstrated in each product type were determined, and the data were analyzed to determine similarities and differences among the product types. This study examined the effect of R\&D outsourcing levels on technology and market knowledge sharing by analyzing four types of products: auxiliary products, core products, exploratory products, and innovative products. 


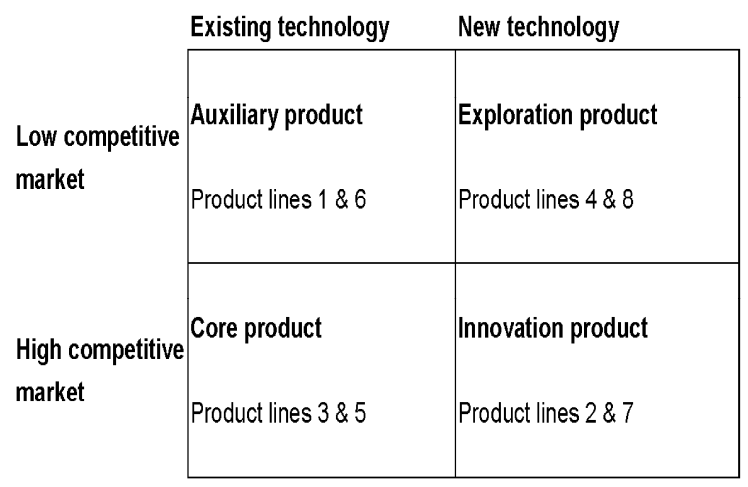

Figure 1. Empirical sampling frame

\subsection{Analysis}

Based on the framing of product types by the brand owner, patterns between R\&D outsourcing levels and knowledge sharing were observed. Data were collected during regular meetings and interviews. Critical observations describing the product types and the $\mathrm{R} \& \mathrm{D}$ outsourcing status of each were inputted into an empirical database. Each type revealed distinct characteristics, and four types of R\&D outsourcing and knowledge sharing associated with each type were explored. The following section describes the various product types in relation to R\&D outsourcing levels and knowledge sharing.

\section{Results}

\subsection{R\&D Outsourcing Strategies}

Each product line belonged to a business unit, and each business unit comprised specific functional departments and various relevant mechanisms for operating models. Therefore, distinct R\&D outsourcing levels were applied to each product line, and contract manufacturers maintained the business model.

\subsection{Auxiliary Products}

Two product lines were classified into the auxiliary product category, and their R\&D was mainly outsourced. The auxiliary product technology was mature and most contract manufacturers in this category designed high-quality products. For example, in Product Line 1, the brand owner outsourced $100 \%$ of R\&D for all models. Although the market volume was high, the market trend gradually declined. The product managers of Product Line 1 explained that the product line was continued because of the potential to raise brand awareness and revenue. A strong willingness to share knowledge with contract manufacturers existed because no resources were dedicated to R\&D. In the regular weekly project meetings, market knowledge and technology knowledge was frequently obtained from contract manufacturers.

Channel customers preferred that the brand owner provide total solutions because it was convenient for channel customers to bundle the major products with auxiliary products to boost sales. For example, the products in Product Line 6 were always bundled with major products. The brand owner outsourced $70 \%$ of R\&D for medium- and low-end models to reduce the labor cost, but the high-end models were developed internally. The product manager of Product Line 6 stated a preference for sharing market knowledge during quarterly business reviews, and invited contract manufacturers to introduce technology trends and applications once every two months.

The main objective of producing auxiliary products was to reduce labor costs and achieve economies of scale. The brand owner preferred higher R\&D outsourcing for this product type. To accomplish effective product planning, the product managers sought to understand the market trend and technology application with contract manufacturers. Therefore, based on the analysis, it was proposed that:

Proposition 1a: Higher R\&D outsourcing is associated with higher levels of technology knowledge sharing between the brand owner and contract manufacturer of auxiliary products.

Proposition 1b: Higher R\&D outsourcing is associated with higher levels of market knowledge sharing between the brand owner and the contract manufacturer of auxiliary products. 


\subsection{Core Products}

Two product lines were classified into the core product category. The core product category contained product lines sold in highly competitive markets and generated major revenue for the brand owner. For example, in Product Line 3, the unit price was higher than that of other IT products, and the unit price secured $50 \%$ of the revenue earned by the brand owner. Although the market trend increased slowly, it was stable and the total market volume was substantial. The brand owner used in-house R\&D for high- and medium-end models to create product differentiation, and outsourced $40 \%$ of $\mathrm{R} \& \mathrm{D}$ for low-end models. The product manager recognized that the goal was to reduce costs, and believed that contract manufacturers possessed the ability to design high-quality, low-end models. The manager preferred to share market information with contract manufacturers, including price trends and competitor statuses (product manager, Product Line 3).

The core product of the brand owner could have been the market leader. For example, Product Line 5 grew during the startup stage and became the leader in this product market. This core product secured $15 \%$ of the revenue. The brand owner secured in-house $R \& D$ for product development, and outsourced only $30 \%$ of $R \& D$ for low-end models. Therefore, the product line director stated that the brand owner possessed strong technology knowledge compared with that of contract manufacturers. This allowed the product managers to build confidence in internal technology development. Therefore, technology knowledge was rarely shared between the two parties (product director, Product Line 5).

The main purpose of producing core products was to maintain the lead position and gain additional market shares. The brand owner preferred in-house R\&D. The product managers were confident in internal technology development and shared market knowledge with contract manufacturers to ensure strong communication. Therefore, based on the analysis, the following propositions were derived:

Proposition 2a: Lower R\&D outsourcing is associated with lower technology knowledge sharing between the brand owner and the contract manufacturer of core products.

Proposition 2b: Lower R\&D outsourcing is associated with higher market knowledge sharing between the brand owner and the contract manufacturer of core products.

\subsection{Exploratory Products}

Two product lines were classified into the exploration category. The brand owner created new business units for new product exploration. The brand owner sought to seize market shares from the beginning, despite the high possibility of failure. For example, in Product Lines 4 and 8, the brand owner dedicated R\&D resources to the exploration of new products. As two product managers stated, this product line was a "secret weapon" and pioneer in its particular market. Sharing technology knowledge with external parties was not considered necessary according to the product director of Product Line 4. Discussing the market knowledge shared between the brand owner and contract manufacturer was challenging because the market was uncertain. Cooperating with contract manufacturers to share the high investment cost was probable, but not certain, according to the product director of Product Line 8 . The main objective of the brand owner, regarding exploratory products, was to be pioneers in the market because other competitors could not compete with the new technology. Therefore, the following was proposed:

Proposition 3: Exploratory products are associated with lower technology and market knowledge sharing between the brand owner and the contract manufacturer, regardless of the level of R\&D outsourcing.

\subsection{Innovative Products}

Two product lines were classified into the innovative product category. The brand owner considered innovative products to be "hero products" that could yield high potential margins. For example, in Product Line 2, the brand owner outsourced $25 \%$ of R\&D for low-end models. The brand owner agreed to cooperate with external parties (e.g., Google) to develop products and to determine the market trend because product design and content application were both crucial in this product line. Therefore, the brand owner did not share market knowledge with the contract manufacturer. The product manager recognized the need to prevent valuable or confidential ideas from being released to competitors through contract manufacturers. This sustained the competitive technology advantage of the firm and improved the ability to create more innovative products in this product line, according to the product director of Product Line 2.

A vast knowledge gap existed between the brand owner and contract manufacturers. For example, in Product Line 7, the business model was specific and the technology level was high. In most models, the brand owner asked contract manufacturers to manufacture only goods and outsourced $20 \%$ of R\&D for low-end models. The contract manufacturers only knew how to manufacture the goods, but it was difficult for contract manufacturers 
to ascertain the proper technology application for total solutions and the business market trend. The product manager of Product Line 7 stated that the brand owner had strong market and technology knowledge compared to contract manufacturers; thus, the brand owner preferred not to share knowledge with them.

The main purpose of producing this product type was creating innovative products to attract customers and subsequently increase profit. The brand owner preferred using a low level of R\&D outsourcing. Based on this analysis, the following was proposed:

Proposition 4a: Lower R\&D outsourcing is associated with lower technology knowledge sharing between the brand owner and the contract manufacturer of innovative products.

Proposition 4b: Lower R\&D outsourcing is associated with lower market knowledge sharing between the brand owner and the contract manufacturer of innovative products.

A detailed list of the R\&D outsourcing strategies, market knowledge sharing, and technology knowledge sharing of each product line is provided in Table 1.

Table 1. Product lines

\begin{tabular}{|c|c|c|c|}
\hline Product Line & R\&D Outsourcing Strategy & Market Knowledge Sharing & Technology Knowledge Sharing \\
\hline \multicolumn{4}{|c|}{ Auxiliary Products } \\
\hline $\begin{array}{l}\text { Product Line } 1 \\
\text { (Display) }\end{array}$ & $\begin{array}{l}\text { 1. Focused on product } \\
\text { planning } \\
2 \text {. The purpose was to gain } \\
\text { economies of scale and } \\
\text { substantial revenue } \\
3 \text {. } \quad 100 \% \text { R\&D outsourcing } \\
\text { for all models }\end{array}$ & $\begin{array}{l}\text { Discussion of market volume and price in } \\
\text { a quarterly business review } \\
\text { Negotiated panel price once per month }\end{array}$ & $\begin{array}{l}\text { Invited contract manufacturers to introduce } \\
\text { new technology quarterly } \\
\text { Unofficial meetings for new technology } \\
\text { applications }\end{array}$ \\
\hline $\begin{array}{l}\text { Product Line } 6 \\
\text { (DVD-ROM) }\end{array}$ & $\begin{array}{l}\text { 1. } \quad 70 \% \text { R\&D outsourcing } \\
\text { for low-end models } \\
2 . \quad \text { Bundled with major } \\
\text { products for sale }\end{array}$ & $\begin{array}{l}\text { Official discussion of market trends in a } \\
\text { quarterly business review }\end{array}$ & $\begin{array}{l}\text { Official introduction of new technology in a } \\
\text { quarterly business review }\end{array}$ \\
\hline \multicolumn{4}{|l|}{ Core Products } \\
\hline $\begin{array}{l}\text { Product Line } 3 \\
\text { (Notebook) }\end{array}$ & $\begin{array}{l}\text { 1. Used product } \\
\text { differentiation to meet customer } \\
\text { preferences } \\
2 . \quad 40 \% \text { R\&D outsourcing } \\
\text { for low-end models }\end{array}$ & $\begin{array}{l}\text { Discussed the market trend and } \\
\text { competition situation with contract } \\
\text { manufacturers to ensure that the direction } \\
\text { was correct }\end{array}$ & $\begin{array}{l}\text { The contract manufacturer attempted to } \\
\text { promote the new technology they produced } \\
\text { to brand owners } \\
\text { The brand owner did not want to share new } \\
\text { technology to secure a competitive } \\
\text { advantage }\end{array}$ \\
\hline $\begin{array}{l}\text { Product Line } 5 \\
\text { (Motherboard) }\end{array}$ & $\begin{array}{l}\text { 1. The brand owner sought } \\
\text { to gain a greater market share } \\
2 . \quad 0 \% \mathrm{R} \& \mathrm{D} \text { outsourcing for } \\
\text { low-end models }\end{array}$ & $\begin{array}{l}\text { The market price was controlled by the } \\
\text { brand owner, who was occasionally } \\
\text { willing to share market perspectives with } \\
\text { contract manufacturers }\end{array}$ & $\begin{array}{l}\text { The brand owner was the leader in } \\
\text { technology regarding this product line, and } \\
\text { was not willing to share technological } \\
\text { knowledge }\end{array}$ \\
\hline \multicolumn{4}{|c|}{ Exploratory Products } \\
\hline $\begin{array}{l}\text { Product Line } 4 \\
\text { (Transformer } \\
\text { tablet) }\end{array}$ & $\begin{array}{l}\text { 1. The brand owner was the } \\
\text { pioneer in this product line } \\
2 \text {. The product line was } \\
\text { specific } \\
\text { 3. Dedicated R\&D } \\
\text { resources }\end{array}$ & \multirow{2}{*}{$\begin{array}{l}\text { The market trend was unclear; therefore, } \\
\text { it was difficult to share market knowledge } \\
\text { between brand owners and contract } \\
\text { manufacturers }\end{array}$} & $\begin{array}{l}\text { The brand owner regarded this product as a } \\
\text { "secret weapon" and new technology was }\end{array}$ \\
\hline $\begin{array}{l}\text { Product Line } 8 \\
\text { (Transformer } \\
\text { notebook) }\end{array}$ & $\begin{array}{l}\text { 1. The brand owner sold the } \\
\text { product and received positive } \\
\text { feedback } \\
\text { 2. Dedicated R\&D } \\
\text { resources }\end{array}$ & & \\
\hline \multicolumn{4}{|c|}{ Innovative Products } \\
\hline $\begin{array}{l}\text { Product Line } 2 \\
\text { (Tablet) }\end{array}$ & $\begin{array}{l}\text { 1. The market had potential } \\
\text { 2. Market demand grew } \\
\text { rapidly } \\
3 . \quad 25 \% \text { R\&D outsourcing } \\
\text { for low-end models produced } \\
\text { by contract manufacturers }\end{array}$ & $\begin{array}{l}\text { The brand owner tried to cooperate with } \\
\text { external parties to determine market } \\
\text { trends, but did not want to share the } \\
\text { information with contract manufacturers }\end{array}$ & $\begin{array}{l}\text { The brand owner wanted to become the } \\
\text { leader and own the "know-how" for this } \\
\text { product line, therefore, the technology was } \\
\text { not shared with contract manufacturers }\end{array}$ \\
\hline $\begin{array}{l}\text { Product Line } 7 \\
\text { (Cloud Server) }\end{array}$ & $\begin{array}{l}\text { 1. The brand owner } \\
\text { cooperated with a contract } \\
\text { manufacturer only for }\end{array}$ & $\begin{array}{l}\text { A vast market knowledge gap existed } \\
\text { between the brand owner and the contract } \\
\text { manufacturer }\end{array}$ & $\begin{array}{l}\text { The brand owner knew how to integrate } \\
\text { new technology for total solution product } \\
\text { applications; the contract manufacturer was }\end{array}$ \\
\hline
\end{tabular}




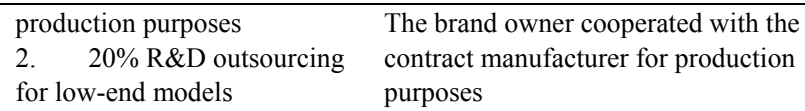
contract manufacturer for production purposes

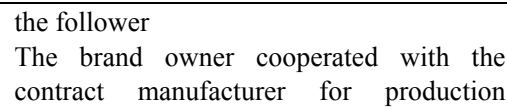

\section{Discussion}

Four product types with various R\&D outsourcing levels were analyzed from the perspective of the brand owner to determine the level of knowledge sharing between the brand owner and contract manufacturers. The brand owner used various levels of R\&D outsourcing for the various product types. Knowledge sharing was affected by the product types. R\&D outsourcing levels similarly affected knowledge sharing regarding the product types, such as core products. The effect of R\&D outsourcing levels on the two types of knowledge sharing was opposite.

Although product types with matched R\&D outsourcing levels caused dissimilar results regarding market and technology knowledge sharing, the brand owner still produced the maximum benefit for each product line. This is consistent with the view that market and technology knowledge is critical for organizational growth, knowledge value creation, and enhancing the competitive advantage of a firm (Conner \& Prahalad, 1996). Lower R\&D outsourcing produced negative effect on technology knowledge sharing. When the brand owner sought to sustain a competitive advantage, lower $R \& D$ outsourcing increased product competency and differentiation because the brand owner allocated in-house R\&D to technology development, rendering knowledge sharing unnecessary. Higher R\&D outsourcing produced a positive effect on technology knowledge sharing. Whereas the brand owner preferred to leverage the knowledge capability of the contract manufacturer, the brand owner preferred to share technology knowledge with each other. However, regarding the exploratory product lines, higher R\&D outsourcing produced a negative effect on technology knowledge sharing because the trend was highly uncertain, and the effect on market knowledge was complex. The analysis revealed that the level of R\&D outsourcing causes diverse results regarding market knowledge sharing, depending on the product type.

\subsection{Auxiliary Products}

The brand owner preferred to share technology with contract manufacturers that possessed powerful R\&D resources. The brand owner employed several contract manufacturers for each product line. Product managers could accumulate numerous opinions and information related to technology, and they used high levels of R\&D outsourcing because the technology was stable. This result is consistent with NPD literature, which indicated that external R\&D resources complement internal R\&D knowledge sources (Ganotakis \& Love, 2012). In addition, the contract manufacturers designed new products for other competitors, and the brand owner attempted to obtain market knowledge of other competitors through the contract manufacturers.

\subsection{Core Products}

The technology trend in the core products category was stable. Contract manufacturers promoted technology they produced for new products to most brand owners. When brand owners accepted the proposals of contract manufacturers, they usually were implementing a "me too" strategy. Therefore, brand owners may not be extremely successful in this competitive market.Brand owners seek to internally develop unique technology to attract customers without sharing this technology to contract manufacturers. As Zahra and George (2002) indicated, in-house R\&D improves products and processes, and facilitates combining the necessary knowledge to successfully introduce new products and processes. However, contract manufacturers possessed the advantage of economies of scale. Therefore, brand owner outsourced fewer R\&D activities for low-end models. These findings are consistent with those of previous studies, which suggested that firms must focus on core competencies and outsource other value-added activities to suppliers (Gottfredson, Puryear, \& Phillips, 2005). Although brand owners attempt to internally create advanced technology for product differentiation, they prefer sharing market knowledge with contract manufacturers to confirm the correct market trend.

\subsection{Exploratory Products}

Brand owners may establish laboratories with R\&D resources to internally develop new technology. Another option for brand owners is to cooperate with a contract manufacturer and share the R\&D cost to reduce the risk. However, in this case, technology competence was not stable and the market situation was unclear to both parties. Therefore, knowledge sharing between the brand owner and the contract manufacturer is difficult. 


\subsection{Innovative Products}

The brand owner indicated that it was crucial to be a leader in advanced technology within this potential market. However, the new technology produced by this brand owner was still in the developmental stage. The brand owner preferred in-house designs for developing new technology and infrequently shared technology knowledge. This is consistent with the view that internal R\&D resources increase the success of innovative products in the market (Roper et al., 2008). In addition, the knowledge regarding new product innovation is derived from in-house R\&D (Ganotakis \& Love, 2012). The brand owner also sought to create new and first-class product specification ideas to meet customer demands. This could allow the market knowledge gap to expand between the brand owner and competitors. In summary, brand owners do not prefer to share knowledge with contract manufacturers because they wish to maintain wide knowledge gaps with competitors.

\section{Managerial Implications}

In the past, when discussing R\&D outsourcing, managers were only required to decide whether or not to keep an R\&D resource. Brand owners discovered that allocating all the resources to sales, marketing, and channel management was both simple and beneficial to the organizations of these brand owners. Contract manufacturers effectively develop high-quality products at a low cost for brand owners. Brand owners usually compete by changing market prices. This is accomplished by consistently using the same product functions produced by the same contract manufacturers. Today, consumers also change their preferences. Consumers value price, quality, and also product differentiation. Consequently, brand owners use internal $R \& D$ resources to design products.

These results reveal several managerial implications. First, managers can judge product statuses based on whether the product involves new technology or existing technology, or is sold in a high-competition market or a low-competition market, according to Table 1. Managers can outsource R\&D to various extents based on the product type to efficiently allocate $R \& D$ resources and maximize benefits for brand owners. Second, managers can use R\&D outsourcing strategies to obtain additional benefits by using knowledge-sharing strategies, which vary according to the product type.

\section{Limitations and Suggestions for Future Research}

This study had some limitations. First, the study investigated R\&D outsourcing strategies by considering these strategies as a single factor that affects knowledge sharing based on various product types. Other factors may affect knowledge sharing, such as product complexity and organizational culture. Second, the brand owner selected for the case study operated in the high-tech industry. Future research can explore the same relationships in other contexts.

\section{Conclusion}

This research primarily contributes to the highly-debated R\&D outsourcing debate by suggesting that the optimal level of R\&D outsourcing, determined by a brand owner in the high-tech industry is most effectively based on product type. The R\&D outsourcing level affects knowledge sharing differently depending on the various product types; therefore, distinguishing between market and technology knowledge is necessary. The framework developed in this study is an analytical tool that can be applied by managers in analyzing R\&D outsourcing strategies and leveraging knowledge sharing.

\section{References}

Araujo, L., Dubois, A., \& Gadde, L. E. (1999). Managing interfaces with suppliers. Industrial Marketing Management, 28, 497-506. http://dx.doi.org/10.1016/S0019-8501(99)00077-2

Artz, K. W., Norman, P. M., Hatfield, D. E., \& Cardinal, L. B. (2010). A longitudinal study of the impact of R\&D, patents, and product innovation on firm performance. Journal of Product Innovation Management, 27, 725-740. http://dx.doi.org/10.1111/j.1540-5885.2010.00747.x

Asmus, D., \& Griffin, J. (1993). Harnessing the power of your suppliers. The McKinsey Quarterly, 3, 63-78.

Belderbos, R., Carree, M., \& Lokshin, B. (2004). Cooperative R\&D and firm performance. Research Policy, 33(10), 1477-1492. http://dx.doi.org/10.1016/j.respol.2004.07.003

Caputo, A. C., \& Palumbo, M. (2005). Manufacturing reinsourcing in the textile industry. Industrial Management and Data Systems, 105(2), 193-207. http://dx.doi.org/10.1108/02635570510583325

Cesaroni, F. (2004). Technological outsourcing and product diversification: do markets for technology affect firms strategies? Research Policy, 33(10), 1547-1564. http://dx.doi.org/10.1016/j.respol.2004.08.003

Chalos, P., \& Sung, J. (1998). Outsourcing decision and managerial incentives. Decision Science, 29(4), 
901-919. http://dx.doi.org/10.1111/j.1540-5915.1998.tb00881.x

Cohen, W., \& Levinthal, D. (1990). Absorptive Capacity: a new perspective on learning and innovation. Administrative Science Quarterly, 35(1), 128-152. http://dx.doi.org/10.2307/2393553

Conner, K. R., \& Prahalad, C. K. (1996). A resource-based theory of the firm: knowledge versus opportunism. Organization Science, 7(5), 477-501. http://dx.doi.org/10.1287/orsc.7.5.477

Danneels, E. (2002). The dynamics of product innovation and firm competences. Strategic Management Journal, 23, 1095-1121. http://dx.doi.org/10.1002/smj.275

Ganotakis, P., \& Love, J. H. (2012). The innovation value chain in new technology-based firms: Evidence from the U.K. Journal of Product Innovation Management, 29(5), 839-860. http://dx.doi.org/10.1111/j.1540-5885.2012.00938.x

Ghemawat, P. (2003). The forgotten strategy. Harvard Business Review, 81(11), 76-84.

Gonzalez, R., Gasco, J., \& Llopis, J. (2005). Information systems outsourcing success factors: a review and some results. Information Management and Computer Security, 13(5), 399-418. http://dx.doi.org/10.1108/09685220510627287

Gottfredson, M., Puryear, R., \& Phillips, S. (2005). Strategic sourcing: from periphery to the core. Harvard Business Review, 83(2), 132-139.

Hagedoorn, J. (1993). Understanding the rationale of strategic technology partnering: interorganizational modes of cooperation and sectoral differences. Strategic Management Journal, 14, 371-385. http://dx.doi.org/10.1002/smj.4250140505

Hansen, M. T. (1999). The search-transfer problem: the role of weak ties in sharing knowledge across organizational subunits. Administrative Science Quarterly, 44(1), 82-111. http://dx.doi.org/10.2307/2667032

Henisz, W. J., \& Williamson, O. E. (1999). Comparative economic organization within and between countries. Economics and Politics, 1, 261-276.

Kankanhalli, A., Tan, B. C. Y., \& Wei, K. K. (2005). Contributing knowledge to electronic knowledge repositories: an empirical investigation. MIS Quarterly, 29(1), 113-143. http://dx.doi.org/10.1108/17410380710828253

Karlsson, C., \& Sköld, M. (2007). The manufacturing extraprise: An emerging production network paradigm. Journal of Manufacturing Technology Management, 18(8), 912-932.

Kautz, K., \& Mahnke, V. (2003). Value creation through IT-supported knowledge management? The utilisation of a knowledge management system in a global consulting firm. Informing Science, 6, 75-88.

Kogut, B., \& Zander, U. (1992). Knowledge of the firm, combinative capabilities, and the replication of technology. Organization Science, 3(3), 383-397. http://dx.doi.org/10.1287/orsc.3.3.383

Laursen, K., \& Salter, A. (2006). Open for innovation: The role of openness in explaining innovation performance among UK manufacturing firms. Strategic Management Journal, 27, 131-150. http://dx.doi.org/10.1002/smj.507

Le Bas, C., \& Sierra, C. (2002). Location versus home country advantages in R\&D activities: some further results on multinationals' locational strategies. Research Policy, 31(4), 589-609. http://dx.doi.org/10.1016/S0048-7333(01)00128-7

Leiblein, M. J., \& Miller, D. J. (2003). An empirical examination of transaction-and firm-level influences on the vertical boundaries of firms. Strategic Management Journal, 24, 839-859. http://dx.doi.org/10.1002/smj.340

Lonsdale, C. (1999). Effectively managing vertical supply relationships: a risk management model for outsourcing. Supply Chain Management: An International Journal, 4(4), 176-183. http://dx.doi.org/10.1108/13598549910284499

Love, J. H., \& Roper, S. (2009). Organizing the innovation process:Complementarities in innovation networking. Industry and Innovation, 16, 273-290. http://dx.doi.org/10.1080/13662710902923776

Nicholls-Nixon, C., \& Woo, C. (2003). Technology sourcing and output of established firms in a regime of encompassing technological change. Strategic Management Journal, 24(7), 651-666. http://dx.doi.org/10.1002/smj.329 
Nilakanta, S., Miller, L. L., \& Zhu, D. (2006). Organizational memory management: technological and research issues. Journal of Database Management, 17(1), 85-95. http://dx.doi.org/10.4018/jdm.2006010106

Oxley, J. E. (1997). Appropriability Hazards and Governance in Strategic Alliances: A Transaction Cost Approach. Journal of Law. Economics and Organization, 13(2), 387-409. http://dx.doi.org/10.1093/oxfordjournals.jleo.a023389

Pittaway, L., Robertson, M., Munir, K., Denyer, D., \& Neely, A. (2004). Networking and innovation: Asystematic review of the evidence. International Journal of Management Reviews, 5(3/4), 137-168. http://dx.doi.org/10.1111/j.1460-8545.2004.00101.x

Quinn, J. B., \& Hilmer, F. G. (1994). Strategic outsourcing. Sloan Management Review, 35, 43-55.

Quinn, J. B. (2000). Outsourcing innovation: the new engine of growth. Sloan Management Review, 41(4), $13-28$.

Roper, S., Du, J., \& Love, J. H. (2008). Modelling the innovation value chain. Research Policy, 37, 961-977. http://dx.doi.org/10.1016/j.respol.2008.04.005

Santoro, M. D., Bierly, P. E., III., \& Gopalakrishnan, S. (2007). Organisational learning from external sources: new issues and performance implications. International Journal of Technology Management, 38(1/2), 1-10. http://dx.doi.org/10.1504/IJTM.2007.013424

Spithoven, A., Frantzen, D., \& Clarysse, B. (2010). Heterogeneous firmlevel effects of knowledge exchanges on product innovation: Differences between dynamic and lagging product innovators. Journal of Product Innovation Management, 27, 362-381. http://dx.doi.org/10.1111/j.1540-5885.2010.00722.x

Tatikonda, M. V., \& Stock, G. N. (2003). Product technology transfer in the upstream supply chain. Journal of Product and Innovation Management, 20(6), 444-467. http://dx.doi.org/10.1111/1540-5885.00042

Venkatesan, R. (1992). Strategic sourcing: To make or not to make. Harvard Business Review, 98-107.

Yin, R. K. (1994). Case study research-design and methods. CA: Sage.

Zahra, S. A., \& George, G. (2002). Absorptive capacity: A review, re-conceptualization, and extension. Academy of Management Review, 27, 185-203.

\section{Notes}

Note 1. Brand owner: In this study, a brand owner is defined as a branded electronics buyer (large international OEM customer or ODM customer).

Note 2. Contract manufacturer: In this study, a contract manufacturer is defined as a supplier possessing an original equipment manufacturer (OEM) or original design manufacturer (ODM) business.

\section{Copyrights}

Copyright for this article is retained by the author(s), with first publication rights granted to the journal.

This is an open-access article distributed under the terms and conditions of the Creative Commons Attribution license (http://creativecommons.org/licenses/by/3.0/). 